\title{
Nevoid Basal-Cell Syndrome: literature review and case report in a family
}

Head and Neck Surgical Services and at the Plastic Surgery Discipline. Medical School of UNICAMP - Campinas, SP, Brazil

The Nevoid Basal-Cell Carcinoma Syndrome (NBCC), or as it is also referred to, basal-cell nevus syndrome or Gorlin-Goltz syndrome, is characterized by multiple early-appearing basal cell carcinomas, keratocytosis of the mandible, and anomalies of the ocular, skeletal reproductive system. We describe four patients in the same family, all of them possessing a large number of skin tumors associated with other typical clinical and X-Ray anomalies of NBCC. The definitive treatment of NBCC has yet to be established, however, early diagnosis is very important as well as the periodical follow-up examination of ten patients, mainly due to the transformations in the skin lesions that may occur.

UNITERMS: Basal-cell carcinoma. Skin tumors. Gorlin-Goltz Syndrome.

\section{INTRODUCTION}

$\mathrm{T}$ The first historical evidence regarding the syndrome goes back to the 11th Egyptian dynasty. The first case of skin manifestation of the nevoid basal-cell carcinoma syndrome or the Gorlin-Goltz syndrome was described by Jarisch and White in $1894(10,19)$. Although only in the middle of this century the clinical findings of the syndrome were systematized by Gorlin and Goltz (4).

The syndrome presents a dominant autosomal transmission $(2,12)$ and one third of the patients do not have previous family history thus suggesting mutation or incomplete penetration of the gene (5).

\section{Adress for correspondence:}

Alfio José Tincani

Rua Luverci Pereira de Souza 1765

Campinas - SP - Brasil - CEP 13084-031
Howell and Anderson (7) estimated a penetration of the gene in approximately $97 \%$ of the cases and close to $75 \%$ of the individuals with NBCC represented premature emergence of multiple basal-cell carcinomas.

The characterization of the gene which causes the syndrome may help with the understanding of pathogenesis of other basal-cell carcinomas. In addition the analysis of the genetic heritage demonstrated that the gene is located in chromosome 9q22.3-q31. The location of the gene offers the possibility that the DNA markers should be used in the evaluation of the survival of these patients as well as allowing the diagnosis patients that have been diagnosed with early symptoms.

The minimum prevalence is one in every 57,000 although 1 in every 200 patients with basal-cell carcinoma present NBCC and the proportion is much larger with patients that develop basal-cellular carcinoma before the age of $19(15,1)$. An enzyme defect may be responsible for the development of NBCC because these abnormalities are multi-systemic. 
The genetic studies suggest that the control of cellular growth is the main function of the gene involved with NBCC.

Also there is the possibility of the transformation of baso-cellular tumors into epidermoid carcinomas and melanoma.

The major clinical manifestations involve the appearance of multiple basal-cell carcinomas, keratocysts of the jaw and skeletal abnormalities especially in the ribs and vertebrae.

The clinical findings involve multiple systems. Typical facial characteristics are found in up to $70 \%$ of the cases consisting of an increase in the occipitofrontal circumference, moderate-hypertelorium, merging of the brows, and an excessive development of the superior orbital ring. Other than the cited tumors, at the skin level one finds keratosis on the soles and palms $65 \%$ of the cases characterized by punctiform and asymetrical. Miliaria, sebaceous cysts and epidermic cysts have also been described.

The bone abnormalities of the ribs, such as its fusion, spina bifida, cervical rib, sacralization of the lumbar vertebrae spinal, deviations such, the presence of pectus excavatum, or carinatum and hamartoma are among the most frequent findings.

Calcified cysts, fibroma and fibrosarcona of the ovaries are also described. Calcifications of the falxes cerebri and the tentorium cerebelli hiperpneumatization of the paranasal sinuses and strabismus in higher numbers of cases (5) (table 1).

\section{CASE REPORT}

Table 1 describes the main findings on of the four patients, all belonging to the same amily. We want to call attention to the large number of basal-cell carcinomas found in every member and, others that arose during follow up.
Table I

Major diagnostic findings in adults with Nevoid Basal-Cell Syndrome

(Naldi et al., Arch Dermatol, 1991)(16).

Typical facial characteristics

Marfan-like aspect

Multiple basal-cell carcinomas

Plantar and palmar keratosis

Miliaria and epidermal cysts

Odontogenic cysts of the mandible

Calcification of soft tissues

(especially falx cerebris) falx cerebris

Bone abnormalities

Rib or bifide fusion

Vertebrae - kifoscoliosis or to spina bifide

Pectus carinatum or excavatum

Snort fourth metacarp

Polydactily or sindactily

Mesenteric cysts

Ocular abnomalities

Congenital cataract, glaucoma, iris coloboma

Tumors

Medulloblastoma, meningeoma, fetal

rabdomyoma, cardiac fibroma, ovarian

fibrosarcoma

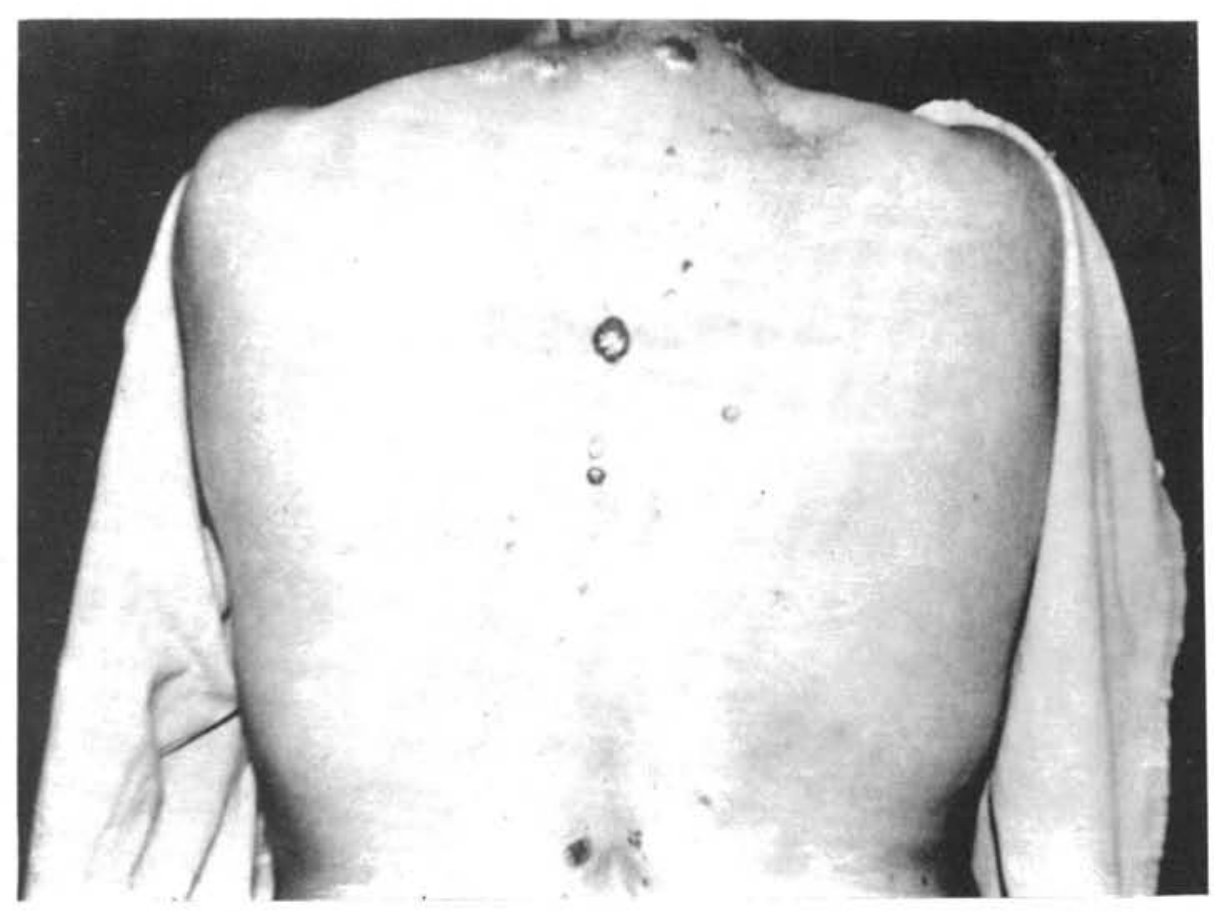

Figure 1: Characteristic lesions of NBCC in the dorsal centerline, most of them being pigmented basal-cell carcinomas. 
Table II

\begin{tabular}{|c|c|c|c|c|c|c|}
\hline Name & Gender & Age years & $\begin{array}{l}\text { Number of } \\
\text { lesions }\end{array}$ & $\begin{array}{l}\text { Lesion } \\
\text { evolution* }\end{array}$ & $\begin{array}{l}\text { Pathologic } \\
\text { anatomy and } \\
\text { number of } \\
\text { lesions }\end{array}$ & $\begin{array}{c}\text { Associated } \\
\text { manifestations }\end{array}$ \\
\hline EAV (fig.1) & $F$ & 55 & 32 & & B.C.C. ${ }^{\star \star}$ & $\begin{array}{l}\text { Typical facial } \\
\text { characteristics } \\
\text { Epidermoide cysts } \\
\text { Ovarian fibrome } \\
\text { Calcification of the } \\
\text { falx } \\
\text { Mandibular cyst } \\
\text { Sacralization of } \\
\text { L5 } \\
\text { Kiphoscoliosis }\end{array}$ \\
\hline JDV (fig.2) & M & 32 & 9 & 10 & $\begin{array}{l}\text { B.C.C. - } 15 \\
\text { Solid epithelioma } \\
-2 \\
\text { Nevocellular } \\
\text { nevus - } 1\end{array}$ & $\begin{array}{l}\text { Typical facial } \\
\text { characteristics } \\
\text { Lumbar scoliosis } \\
\text { Hyperteleorbitism } \\
\text { Sacralization of } \\
\text { L5 } \\
\text { Mandibular cyst }\end{array}$ \\
\hline AMV & $\mathrm{F}$ & 29 & 6 & & $\begin{array}{l}\text { B.C.C - } 5 \\
\text { Melanocytic } \\
\text { nevus - } 5\end{array}$ & $\begin{array}{l}\text { Typical facial } \\
\text { characteristics } \\
\text { Erosion of the } \\
\text { sella tursica }\end{array}$ \\
\hline ALV (fig.3) & $M$ & 20 & 7 & 2 & $\begin{array}{l}\text { B.C.C - } 7 \\
\text { Nevocellular } \\
\text { nevus - } 1 \\
\text { Microinvasive } \\
\text { B.C.C. - } 1\end{array}$ & $\begin{array}{l}\text { Typical facial } \\
\text { characteristics } \\
\text { Mandibular cyst }\end{array}$ \\
\hline
\end{tabular}

* Lesion Evolution - Number of lesions that appeared during patient's follow-up

** B.C.C. - Basal-Cell Carcinoma

Among the single basal-cell tumors, the percentage of solid tumors is high $(88.9 \%)$. According to the results of McKnight et al. (15); Maddox (13); and a study by Jackson and Gardere (9), the frequency of the different subtypes of basal-cell tumors found in patients with NBCC (is solid type $72 \%$, cystic $19 \%$, sclerodermiform $17 \%$, adenoid 27\%, and superficial 6\%). Approximately one third of the patients show two or more types of tumors. Mason discovered in 1965 (14) that out of the 370 tumors examined, 11 presented osteoids or associated bone tissue.
This study showed that it is not possible to diagnose NBCC based on histologic examination solely.

NBCC is a good study model for oncogenesis, particularly the interaction between environmental and genetic factors.

Many findings suggest that the primary function of the gene is the control of cellular growth. The pattern of multisystemic malformations presented suggest that its activity influences the three germinative tissues of the embryo (2). 


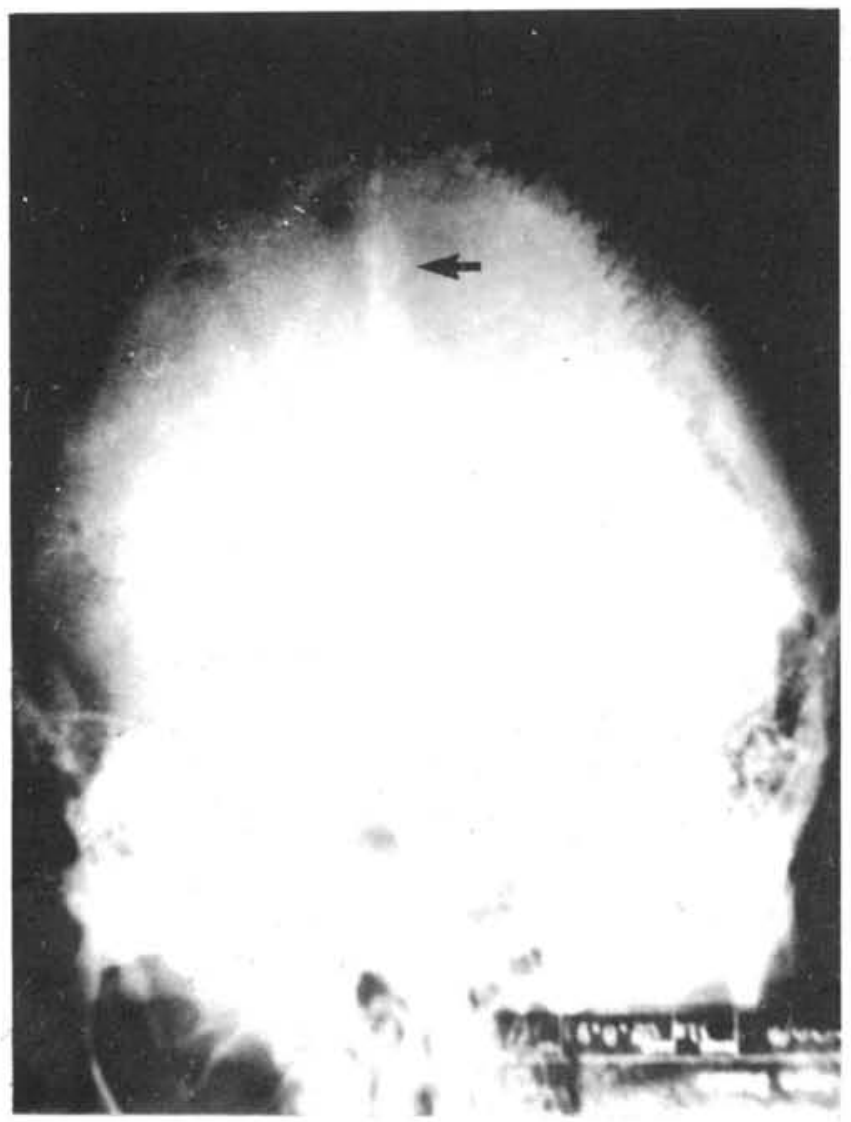

Figure 2: The arrow shows calcification areas in the falx cerebri

Biochemical studies try to characterize the association of the excessive prostaglandin level with the aggressive growth of the basal-cell carcinomas, as well as with its effect on the bone reabsorption present at the formation of odontogenic cysts of the jaw $(6,18)$.

The differential diagnosis of NBCC must be made with the Bazex Syndrome, Rombo Syndrome, and the Rasmussen Syndrome (5). The present of a large cranial circumference and vertebral or rib abnormalities in children without a family history should be an indication for further investigations.

The variety of clinical signs constitute a diagnostic problem. Some of these signs are seen in less than $10 \%$ of the described cases, and there are a number of possible associations (medulloblastoma, meningioma, metacarpus brevis, palate and labium fissure, congenital cataract, glaucoma, coloboma, fibroma, etc.) (5).

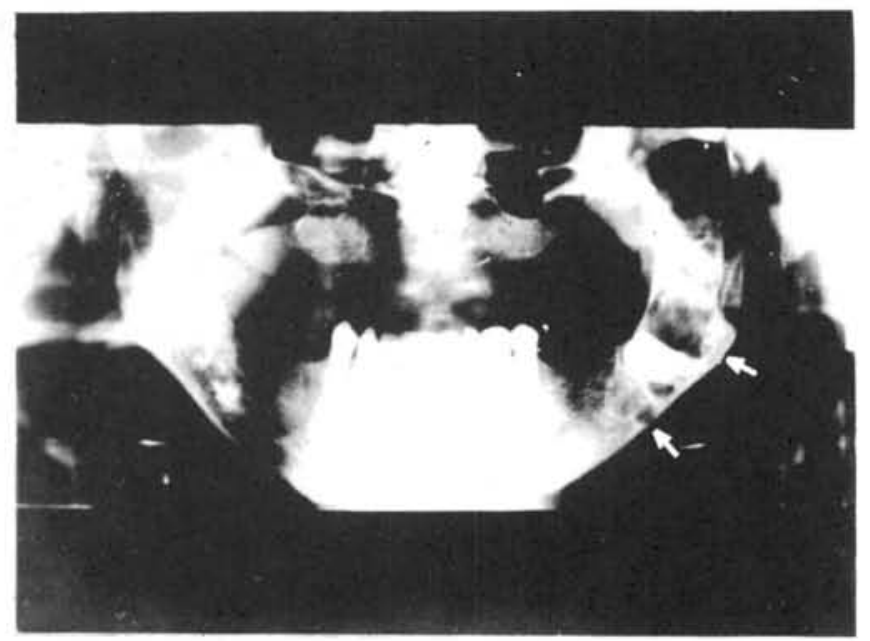

Figure 3: Cysts in the mandibular arch (arrows)

In view of the frequent pathologic skin modifications, the follow-up of patients every 3 to 6 months is required particularly between puberty and the age of 35 , mainly because of the possible appearance of epidermoid carcinoma and cutaneous melanoma at the lesions. Special attention must be given to lesions located near the natural orifices (ears, eyes, nose) due to their potential destruction by the invasion of the tumors.

The treatment in most cases is the surgical removal of the lesion because of its well known aggressive evolution. In some cases of small lesions treatment can be cryosurgery and electrocauterization, as well as curettage (16). The real value of topical immunotherapy and the use of 5fluoracil are under study. The use of 13-cis-retinoic acid taken orally and in high dosages seems to be effective in the prevention of tumor appearances, as well as in the reduction of the growth rate of old lesions (16).

The complete removal of the mandibular cysts is necessary due to the high rate of relapse (4).

The association with radiotherapy in the treatment may not be advisable, due to the fact that the exposure to radiation stimulates the appearance of new lesions and that it requires large areas to be irradiated. The association between NBCC and 
medulloblastoma has been firmly established by the appearance of the tumor in $20 \%$ of patients with NBCC. Patients with NBCC and medulloblastoma and treated with radiotherapy have shown a higher rate of sarcomatous transformation of ovarian fibromas as well as the appearance of a large number of skin tumors at the site where the radiotherapy was applied (1).

In literature there are descriptions of $\mathrm{NBCC}$ cases in families of many different ethnic backgrounds $(3,11,17)$.

\section{CONCLUSIONS}

NBCC is a rare entity and little is known regarding its physiopathology. A precise and early diagnosis is of utmost importance in order to improve the approach to skin lesions, thus avoiding their consequences.

Solar protection is important for all patients and a periodic follow-up in addition to genetic counseling is necessary.

\section{RESUMO}

Introdução: A Síndrome do Nevo Basocelular (SNBC), também chamada de Síndrome do Carcinoma Nevóide Basocelular ou Síndrome de Gorlin-Goltz, caracteriza-se por múltiplos carcinomas basocelulares de aparecimento precoce, cistos em mandibula, além de outras anomalias como as ósseas, problemas oculares e no aparelho reprodutivo. Conclusão: $O$ tratamento definitivo da SNBC ainda nāo foi bem estabelecido, porém ressalta-se a importância do diagnóstico precoce, além do seguimento periódico dos pacientes, principalmente devido às transformaçōes das lesōes da pele que podem ocorrer.

\section{REFERÊNCIAS BIBLIOGRÁFICAS}

1. Evans D.G.R.; Farndon L.D.; Burnell H.; Rao Gattamaneni; J.M. Birch. The incidence of Gorlin syndrome in 173 consecutive cases of medulloblastoma. Br J Cancer 64: 959-961,1991.

2. Farndon P.A.; Del Mastro R.G.; Evans D.G.R.; Kilpatrick M.W. Location of gene for Gorlin syndrome. Lancet 339: 581582,1992 .

3. Gao J.; Zhang Y.; Xu M.; Zou Z.; Chen Z.; Gu Z.; Zhu B. Studies on the genetics of basal cell nevus syndrome in one family. Chin Med J 98: 538-542, 1985.

4. Gorlin R.J. and Goltz R.W. Multiple novoid basal-cell epithelioma jaw cysts and bifid rib.N Eng J Med 262: 908$912,1960$.

5. Gorlin R.J. Nevoid basal-cell carcinoma syndrome. Medicine 66: $98-113,1987$.

6. Hauenstein H. and Schettler D. Untersuchungen Über prostaglandine bei kieferzysten. Dtsch Zahnarztl Z. 40: 595601,1985 .

7. Howell J.B. and Anderson D.E. The nevoid basal-cell carcinoma syndrome. In Andrade R at all editors. Cancer of the skin. W.B. Sanders, 883-898, 1976.

8. Howell J.B. Nevoid basal-cell carcinoma syndrome.J Am Acad Dermat 11:98-104, 1984.

9. Jackson R. and Gardere S. Nevoid basal cell carcinoma syndrome. Canad Med Assoc J 105: 850-862, 1971.
10. Jarisch W.. Zur lehre von den Hautgeschwülsten. Arch Dermatol Syphilol 28: 162-222, 1984.

11. Khoubesserian P.; Baleriaux D.; Toussaint D.; Telerman-Toppett N.; Coers C.. Adult form of basal-cell naevus syndrome: A family study. Neurology 226:157-168, 1991.

12. Lindenberg H. \& Jepsen F.L.. The nevoid basal-cell syndrome. Histopathology of the basal-cell tumors. J Cut Pathol 10:6873,1983 .

13. Maddox W.E.. Multiple basal-cell tumors jaw cysts and skeletal defects. Thesis University of Minnesota. Apud Gorlin R.J. and Sedano H.O.. Birth Def 8:140-148, 1971.

4. Mason J.K.; Helwig E.B.; Graham J.H.. Pathology of the nevoid basal-cell syndrome. Arch Path 79:401-408, 1965.

15. McKnight C.K. and Magnusson B.. Tumors in Iceland. Malignant tumors of the skin - a histological classification. Path Microb Scand Sect A 87:37-44, 1974.

16. Naldi L.; Marchesi L.; Locati F.; Cainelli T.; Multiple papular and nodular lesions in a tall woman. Arch Dermatol 127: 1717 - 1722,1991.

17. Ryan D.E. and Burkes E.J.. The multiple basal-cell nevus syndrome in a Negro family. Oral Surg 55: 127-32, 1973.

18. Vanderveen E.E.; Grekin R.C.; Swanson N.A.; Kragballe K.. Arachidonic acid metabolites in cutaneous carcinoma: evidence suggesting that elevated levels of prostaglandins in basal cell carcinomas are associated with an agressive growth pattern. Arch Dermatol 122:407-412, 1986.

19. White J.C.. Multiple benign cystic epitheliomas. J Cutan Genitourin Dis 12: 477-484, 1984. 